\title{
Od Pyjasa do Popiełuszki. Obraz „męczennika politycznego" w poezji
}

Agnieszka Dębska 


\section{Agnieszka Dębska}

\section{Od Pyjasa do Popiełuszki. Obraz „męczennika politycznego” w poezji}

\footnotetext{
dy w grudniu 1980 roku odsłonięto wywalczony przez gdańskich robotników Pommik J Poległych Stoczniowców, na murze okalającym plac przed stoczniową bramą znalazl się napis:
}

Oddali życie, abyś ty mógł żyć godnie.

To bardzo znamienne słowa. Nadają one upaniętnionej śmierci sens teleologiczny. Zastrzeleni robotnicy nie są już przypadkowymi ofiarami „.wydarzeń” czy „wypadków”, jak często o nich w oficjalnej, eufemizującej terminologii mówiono, ale aktywnym podmiotem historii. To oni „oddali życie”, a oddać można coś - z mocy definicji - jedynie na skutek świadomego wyboru; ponadto ich śmierć zostala podniesiona do godności ofiary. Zaś „godne życie" było w grudniu 1980 roku niewątpliwie synonimem nadziei na wolną Polskę. W ten sposób polegli stoczniowcy zostali wlączeni w ciąg tradycji niepodległościowej, stali się kolejnym ogniwem w łańcuchu walczących i ginących za ojczyznę.

Proces ten zachodzil jednak powoli. Nic od razu zastrzeleni robotnicy dolączyli do grona bohaterów i męczenników „sprawy polskiej”. W 1970) roku nikomu by nie przyszło do głowy, aby ich w ten sposób nazywać. Zresztą także uczestnicy tamtych zajść nie odwolywali się wówczas do tego typu określeń. Świadectwa świadomości robotników w postaci okolicznościowych ballad nowiniarskich z tego czasu jednoznacznie lokują ówczesny konflikt na plaszczyźnie ekonomicznej bez odniesień politycznych ${ }^{1}$. Jest to do tego stopnia wyraźne, że jedyny utwór, który wprowadza patriotyczne samookreślenie - stynna Pieśí o Janku z Gdyni z frazą:

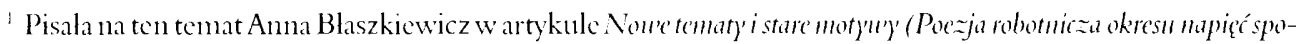
(crzn'r(h), ..Kultura", Paryz 1985. ur 7/8.
} 


\title{
Za chleb i wolność, za nową Polskę
}

— ıważany bywa bądź za tekst późniejszy bądź też podlegający po roku 1970 przeróbkom².

Także w ówczesnych literackich świadectwach tych wydarzeń próżno szukać odniesień, które wpisywałyby się w model patriotyczny. Oczywiście istotną rolę odegrały tu względy cenzuralne, ale nawet po 1976 roku, gdy wiersze pisane pod wpływem zajść na Wybrzeżu ujrzały światło dzienne dzięki możliwościom, jakie oferowaly niezależne oficyny, nie znalazło się tam nic, co by ten obraz zmienialo. Owszem, wzmianki o grudniowej tragedii były obecne w wielu utworach publikowanych $w$ drugim obiegu, ale wprowadzano je nadzwyczaj dyskretnie, tak jakby nadal obowiązywala opisana przez Joannę I Iobot „strategia «obejścia” zakazów cenzury" ". Pojawialy się więc zaledwie pojedyncze sygnały - i to koncentrujące się prawie wylącznie na zewnętrznym, oznakowym wymiarze dramatu, reprezentowanym przez krew, a zwłaszcza - bardzo charakterystyczne - ,polewaczki czyszczące ulice z krwi”, o których pisali Stanisław Stabro czy Jacek Bierezin ${ }^{\dagger}$. Dominującym czynnikiem było wówczas świadectwo dystansı, co prawda sprzężone z poczuciem bezradności, ale sprowadzające nieuchromnie wyrażający je podmiot na pozycję biernego „obserwatora historii”, co wspólbrzmialo z utrwalonym toposem grudniowych wydarzeń odtworzonym potem przez Andrzeja Wajdę w filmie Cźton'iek z żłaza - na przykład w scenie, w której robotniczy pochód przechodzil koło akademika.

Wajda w symbolicznym skrócic pokazywał drogę, jaką odbyło polskie społeczeństwo od tantych dni do Sierpnia 1980, od wewnętrznych podziałów i wzajemnej nieufności do momentu zespolenia wokół magicznego centrum - Gdańskiej Stoczni. Zapis analogicznego procesu obserwować można w poezji. Ohcjmuje on również sposób przedstawiania zajść z grudnia 1970 roku. Z perspektywy Sierpnia o wypadkach sprzed dziesięciu lat zaczyna się mówić w nieco innych kategoriach. Na przykład w ten sposób:

\author{
Robotnicy Wybrzeża \\ stają się znowu \\ nadzieją naszych \\ zbolalych serc \\ stają się znowu \\ sercem nas wszystkich" ${ }^{\prime}$.
}

2 Zob. ibidem. s. 149.

${ }^{3}$ Zob. J. Hobot, Gra z conzurạ u' poézi Nourcj Fali (1968-1976), Kraków 2000) (zwlaszcza rozdzial Autorska strategia "obejsciala" zakazón' cenzant').

+ Zob. wicrsze Delacroix 1970 S. Stabry z tomu Ten wiersz, któny ma na imię Polska. [b.w.], Wroclaw 1978 (Bibliotcka .,Agory") i I' potowic ¿ycia J. Bicrezina z tomu pod tym samym tytulem, Warszawa 1980 (NOWA).

"Jak ująl to Antoni Pawlak w poświęconym tanty'm wydarzeniom pocmacic Dojrzc'manie z tomu Cżter' poe'mat)' Gdańsk 1983 [b.w:].

'L. Herbst. Robotmicy Hjorzċa..., w: idem. IVjzmania. Wroctaw 1981 (Świt). Wiersz datowany na sierpień 1980. 
Widać tu wyraźnie, że poczucie narodowej solidarności, wywodzące się z sierpniowej atmosfery, zostaje w swoisty sposób „antydatowane” — rozciągnięte także na poprzednie wystąpienie „Robotników Wybrzeża”. Co więcej, wtedy właśnie po raz pierwszy pojawia się przekonanie o celowości tamtych zdarzeń. Jawią się one jako przygotowanie, konieczny prolog do bezkrwawej sierpniowej rewolucji. Śmierć sprzed dziesięciu lat zaczyna być postrzegana w kategoriach ofiary, do lask wraca romantyczna koncepcja ziarna. Mówi o tym wprost aforystyczny wiersz Tomasza Jastruna:

\section{Z krwi zabitych stoczniowców Wyrósł nagle krzyż Jak bolesne musiato być ziarno Które tak dlıgo czekato ${ }^{7}$}

Z krwi wyrasta krzyz - to bezpośrednie nawiązanie do słynnego krzyża upamiętniającego zabitych, ustawionego w czasie strajku w pobliżu stoczniowej bramy, ale z tamtej kıwi „wyrasta” także całe doświadczenie sierpniowego protestu. Potwierdzają to również sami robotnicy, którzy w okolicznościowej poezji strajkowej określają siebie jako spadkobierców grudniowych wydarzeń

Jednak to dopiero specyfika doświadczenia Sierpnia 1980) umożliwila takie postrzeganic przeszlości. Odświętna atmosfera tego czasu, poczucie wyjątkowości dzicjowego momentu stworzyło odpowiednie warınki do posłıgiwania się stylem wysokim i określeniami zaczerpniętymi z romantyczno-patriotycznej tradycji. Śmierć postrzegana jako „ofiara za sprawę” świetnie się w tych kategoriach mieściła. Dlatego też później — przy okazji kolejnych rocznic i uroczystości świętowanych w czasie szesnastı miesięcy legalnej dzialalności Związku — ten martyrologiczny idiom cieszył się ogromną popularnością. Konsekwentnie wywodzono również tradycje „Solidarności” z poprzednich wystąpień robotniczych — tych z 1956 i 1970 roku, interpretując je tak, aby nabraly wymowy jednoznacznie patriotycznej. Widać to szczególnie w okolicznościowych wierszach pisanych „ku czci” przy okazji odsłaniania kolejnych pomników. I tak na przyklad autor tekstu zatytułowanego Pod ramionami gdaniskich krzyży zajścia z grudnia 1970 roku wspomina w następujący sposób:

Szesnastego grudnia lat siedemdziesiątych

Straciło życie tyle istnieni ludzkich

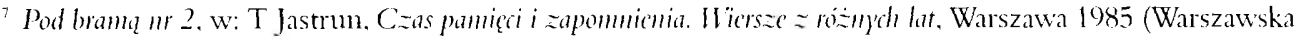
Niezalcżna Oficyna Poctów i Malarzy Przedświt). s. 13.

"Danuta Dą̧browskil pisala naweto „męczeniskim” aspekcic obrazu grudniowych wypadków obecnym w poezji sicrpniowej: „Poprzez powszechnic czytelną symbolikẹ religijno-patriotyczną Grudzicń 1970 roku uzyskuje wykladniç mesjanistyczna.jest przykladem ofiary i cierpień stanowiących konieczną cenç przyszlej wolności. Uczestnicy wydarzeń umieszczeni zaś zostaja w dlugim ciagu podobnych męczenników. ciągle obec-

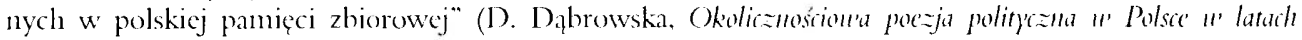
1980-1990, Szczecin 1998, s. 55).
} 
Tak siç pozbywano Polaków „Wyklętych”

Za to, że żądali Praw Obywatelskich".

Pamięć o przyczynach robotniczego protestu została tu ewidentnie przefiltrowana przez późniejszą upolitycznioną świadomość. Interpretowanie wystąpień grudniowych w kategoriach walki o prawa obywatelskie możliwe jest dopiero po lekcji Sierpnia. Ślady tej lekcji widoczne są również w amatorskich wierszach pisanych dla uczczenia 25 . rocznicy wydarzeń poznańskich"1".

Jednak nadawanie robotniczym protestom wymowy politycznej nie jest wyłącznie domeną twórczości amatorskiej. Podobnie postępują liczni autorzy profesjonalni, którzy podejınują tę samą tematykę. Oni także ukazują „Solidarność” jako owoc ofiary zlożonej przez stoczniowców w grudniu 1970. Taką myśl wyraża na przykład Joanna Kulmowa ${ }^{11}$ czy Tadeusz Szyma. Ten ostatni pisze:

I dopóty nie spoczną w pokoju

Pogrzebani nocą, ludzie prości,

Aż obdzielą wszystkich pospołu

Z chleba życia kruszyną wolności ${ }^{12}$.

A więc to właśnie zabici przynoszą żyjącym wolność, ich śmierć jawi się jako jej konieczna cena. Z drugiej strony, rozmiar wyrządzoncj krzywdy potęguje określenie „ludzie prości”. Prostota i bezbronność pokrzywdzonycl świadczy przeciw oprawcom - ten typ argumentacji wykorzystywany będzie także później, w stanie wojennym. Zresztą wspólbrzmi on z znanym utworem Czeshawa Miłosza Któn's skrzyudziteśs - szczególnie mocno się tutaj aktualizującym, gdyż jego fragment umieszczono na gdańskim pomniku.

Ponad to sam pomnik ze swą charakterystyczną symboliką krzyża i kotwicy sprzyjał wydobywaniu wątków męczeńskich. Widać to wyraźnie w wierszu Janusza Stanisława Pasierba, który, opisując monument, sięga po metaforę Golgoty ${ }^{13}$. W miarę upływu czasu symbolika gdańskich trzech krzyży stawała się też coraz bardziej uniwersalna. Nie oznaczały one już tylko pamięci o wydarzeniach Grudnia 1970, lecz zmieniały się - szczególnie w okresie stanu wojennego - w powszechny znak narodowej martyrologii. Bylo to następstwem podwójnej projekcji: gdański pomnik odzwierciedlał męczeniską interpretację protestów z Grudnia 1970, sam zaś stawal się jednym z czynników współtworzących martyrologiczną ikonografię stanu wojennego.

\footnotetext{
"Wiersz podpisany „Kazimierz Majlinga z Jastrzçbia” drukowany w antologii Poezja odmon'y', Warszawa 1981 (Wydawnictwo im. gen. E. Nila-Ficldorfa), s. 12.

3) Szerzej na ich temat pisalam w artykule Czeruriec 1956 " poc $\approx j i$ (zob. "Napis” 20)(0), seria VI).

"Na przyklad w wicrszu Kizy'uda kamicmicm, w: J. Kulmowa, Klamstu'o gotgloic (1980-1982), Szczecin 1988 (Szczecińska Oficyna ,.Solidarność”).

12 T. Szyna, Sty'gmatu knu'i podkuty' but..., . Tygodnik Powszechny” 1980, nr 50, s. 8.

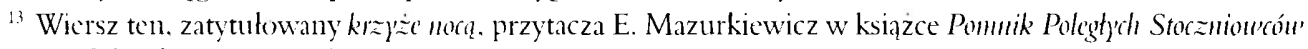
1970. Gdańsk 19\%0, s. 15-16.
} 
W rezultacie nagłej patetyzacji języka literatury wywołanej przez upodnioślające doświadczenie Sierpnia, w okresie stanı wojennego możliwy będzie, zwłaszcza na poziomie popularnej twórczości amatorskiej, każdy nieomal zabieg w obrębie idiomu romantyczno-patriotycznego; co oczywiście przyczyıi się do wyprodıkowania ogromnych ilości kiczu. Znamienny jest fakt, że poezja tego czasu zostaje specjalnie wyczulona na śmierć - chętnie przypomina postaci ,męczenników politycznych” z przeszłości i łączy je z zabityni po 13 grudnia. Dokonuje się też wtedy zastanawiająca z dzisiejszej perspektywy (acz pewnie wytłumaczalna) hiperbolizacja ofiar — na podstawie lektury ówczesnych wierszy można odnieść wrażenie, że zabitych było znacznie więcej niiż w rzeczywistości $i^{1+}$.

Pierwszymi i najbardziej wyeksponowanymi męczennikami stanu wojennego są gómicy z kopalni „Wujek”. Tu zıów znajduje zastosowanie schemat martyrologiczny, z wszystkimi tego konsekwencjami, zwłaszcza ideą ofiary zlożonej za sprawę, ale pojawia się wątek nowy — jest to nadanie opisywanej śmierci wymiaru religijnego. Tym różnią się wiersze pisane po 13 grudnia od utworów wcześniejszych; jeśli tam śmierć była poświęceniem, to dokonywanym w imię wolności czy lepszego jutra, tutaj natomiast zyskuje ona wymiar sakralny. To zapewne skutek uboczny obecnego w poezji popularnej przeniesienia konfliktu na płaszczyznç religijna - stan wojenny to po prostu kolejna odslona w odwiecznej walce dobra ze zlem. A zatem można zabitych gómików traktować jako dar złożony Bogu - ofiarę uświęcająca „Solidarność" poprzez cierpienie jej niewinnych męczenników. Dlatego możliwe są modlitewne wezwania w rodzaju:

\section{O Panie, wspieraj „Solidarnośč,}

Górniczą przyjmij od niej krew ${ }^{15}$.

Tekstów poświęconych zabitym górnikom powstało bardzo dużo. Wynika to pewnie stąd, że wydarzenia w kopalni „Wujek” były ogromnym wstrząsem, przeżyciem, które poruszyło opinię publiczną, a także zmieniło obraz stanu wojennego - nie może on być już dłużej przedstawiany jako operacja bezkrwawa. Stąd też zamykające jeden z wierszy pytanie: „Gdzie twe czyste ręce, generale?" "t, które — jak zauważył Mieczysław Inglot — nawiązuje do przemówienia generala Jaruzelskiego z 13 grudnia ${ }^{17}$. Rzeczą charakterystyczną jest również powtarzająca się $w$ wielu utworach niedokladna liczba zabitych. Wszystkie teksty mówią o siedmiu ofiarach, podczas gdy w rzeczywistości zginęło dziewięciu gómików (w tym dwóch zmarło w szpitalı). Być może wynika to z chaosu informacyjnego, jaki cechowal początek

${ }^{1+}$ Tomasz Żukowski zauważa: „W świetle wierszy o stanie wojennym Polska po 13-tym grudnia to kraj po hekatombic. Opozycjonistom i zwyklym ludziom stale zagraża śmicré. Egzckucja lub wiçzienic jest jedynym możliwym końcem zbuntowanycl. W krajobrazic dominuje "skrwawiona zicnia», "ukrytc kostnice» i "trumny ofiar». Patos walki opozycyjncj budowany jest przez stake zagrożenic śmicrcią" (T. Zukowski, Bunt u'edle" schematu, .Teksty Drugie" 1999. nr 3, s. 81).

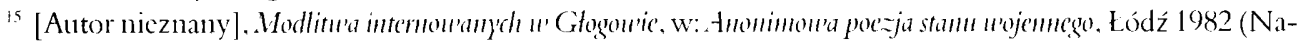
kladem „Solidarności Walczącej” i ..Naszego (ilosu”). s. 17.

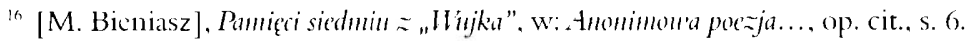

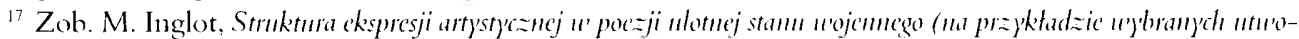
rúu'). .Litcratura i Kultura Popularna”. t. 3. Wroclaw 1992, s. 113. 
stanu wojennego. Z powodu niedostatku oficjalnych informacji krążyły rozmaite, często wyolbrzymione, relacje z przebiegu wydarzeń. Michał Głowiński zanotowal:

Przez dlugi czas nie podawano nazwisk poległych górników (...), co od razu budziło podejrzenie, że liczba ofiar jest większa niż wymieniona w komunikacie $^{1 \times}$.

Ostatecznie jednak upowszechnił się przekaz o siedmiu zabitych — również dzięki poezji, którą zapewne traktowano jako wiarygodne źródło informacji.

Na szczęście, oprócz calej masy stereotypowych ujęć, wierszy pisanych ku czci zabitych, tworzących legendę kopalni „Wujek” czy podkreślających ogrom zbrodni poprzez wskazanie dysproporcji sił i uzbrojenia — jak w anonimowej Pieśni o siedmin, w której czytamy:

Ich było tylko siedmiu

mieli

za broń - zniszczone pracą ręce

górniczy drelich

wiarę w Boga

nic więcej!

— istnieją także utwory, które traktują ten temat w sposób bardziej indywidualny. Choć i one często wykorzystıją stale tropy - na przyklad metaforyczne znaczenia związane z pracą podziemmą" ${ }^{21}$. Ten typ pisania o zabitych gómikach wyróżnia zwłaszcza wiersze, które można określić jako utwory pierwszej reakcji. Później zmienia się nieco kształt twórczości opisującej pogrudniowe realia - zmierza ona w stronę większej indywidualizacji, zarówno w zakresie przedstawianego przedmiotu, jaki i sposobu jego ujęcia. W tym kontekście również wydarzenia w kopalni „Wujek” zostają przeniesione ze sfery doświadczenia symbolicznego, wspólnego do sfery indywidualnej. Gómicy nie sąjuż symbolami - dowodami przemocy reżimu czy też męczennikami za sprawę, ale pojedynczymi ludźmi, których dotyka tragedia. Tematem wierszy staje się właśnie taki lıdzki wymiar nieszczęścia. Zabici to już nie tyle „górnicy” czy symbolicznych niemal ,siedmiu”, ale konkretne osoby z własnymi biografiami i rodzinami. Znak-ofiara zmienia się w materię opowieści. Może nią być na przykład relacja rannego górnika, opis ostatnich chwil towarzyszy, wypowiedzi rodzin zabitych ${ }^{21}$. Tego typu utwory róż-

${ }^{1 *}$ M. Glowiński, Mon'a u' stanie obleżenia (1982-1985). Warszawa 1996, s. 35 . O chaosie informacyjnym towarzyszacym początkuwi stanu wojennego oraz o plotkach doryczących miçdzy innymi liczby zabitych w kopal-

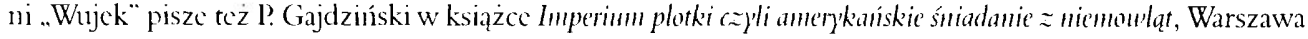
$200(1)(z o b . s .+8-49)$.

14 Anomimon'a poesja..., op. cit.. s. 7.

21) Por. na ten temat M. Inglot. Struktura ekspresji antystyiznej... op. cit. s. 111-114. Tak jest miçdzy innymi w drukowanym pod psendonimem .Mat." wierszu Micczyslawy Buczkówny Strajk oknpacyiny' (w: Antologia I'ierszy w'ojemly ph. opr. Inga [1. Snolka], Jot Em [J. Markicwicz]. Spectator [L. Szaruga]. Warszawa 1982, NOWA); w Rékach Tomasza Jastruna (T. Jastrun, Czas pamięci.... op. cit.) i innych utworach.

${ }^{21}$ Por. np. wiersze W. Paźniewskiego 4. „Nic mogeg sobie l'szjstkiego przypommiéc...” (w: [W. Paźniewski] A. Za-

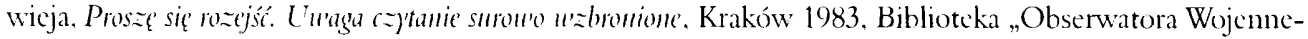


nią się od omówionych poprzednio dużo większym stopniem konkretności - są zapisem szczegółów, osobistym przekazem opowiadającego.

Takie „widzenie przybliżone” pojawia się też w wierszach poświęconych innym osobom, których śmierć łączono z wprowadzeniem stanu wojennego. Postać Bogdana Włosika (zabitego podczas demonstracji w Nowej Hucie, 13 października 1982 rokı) była obecna już w popularnej poezji amatorskiej, tam jednak jego portret kreślono na miarę ludowego hero$\mathrm{sa}^{22}$. Powstała nawet ballada nowiniarska opisująca jego ostatnic chwile ${ }^{2.3}$. Najbardziej znany wiersz na ten temat to niezwykle gorzki tekst Jana Polkowskiego „O Nonej to Hucic piosenk ", zbudowany wokól metafory przedstawiającej zabitego chlopca jako trwały pomnik władzy ludowej. Wydarzenic to powraca także w twórczości innych poetów - Lecha Palczewskiego, Tadeusza Zaleskiego--Isakowicza ${ }^{25}$. Ten ostatni przedstawia, podobnie jak to było w przypadku utworów poświęconych gómikom, odheroizowany portret zabitego, koncentrując się nie na historycznym znaczeniu jego śmierci, ale na ludzkim wymiarze bólu rodziców zastrzelonego chlopca.

Wiele tekstów, wydobywając na plan pierwszy taką właśnie prywatną, ludzką perspektywę doświadczerí stanu wojennego, chętnie odwołuje się do obrazu rodziców, zwłaszcza matki cierpiącej po utracie syna. Obraz ten jest wszakze dodatkowym oskarżeniem pogrudniowego ładu, który nie tylko pozbawił ludzi wolności i nadziei, ale także przyczynil się do osobistych dramatów - ıtraty bliskich. Poruszające portrety matek ofiar tworzą między innymi Joanna Kulmowa czy Anna Kamieńska. Bardzo znamienny wydaje się tı zwłaszcza wiersz Wiktora Woroszylskiego opisujący wspólnotę matek „zannordowanych synów”26".

Szczególnie wyeksponowana zostaje postać matki w poezji pisanej po śmierci Grzegorza Przemyka (zmarł 14 maja 1983 roku, w dwa dni po pobiciu w komisariacie przy ulicy Jezuickiej w Warszawie). Przyczynił się do tego zapewne i młody wiek zabitego, i fakt, że jego matka byla osobą znaną w kręgach opozycyjnych. Zresztą znaczna część utworów nawiązujących do tej tragedii jest dedykowana Barbarze Sadowskiej ${ }^{27}$. Obraz cierpiącej matki ksztaltowany bywa na wzór piety. W oskarżycielskim tekście I Ianny Grodzickiej-Królak czytany:

go”), G. Bialkowskicgo Opouriem mim ouszystkim ([G. Bialkowski|, A. Szymanck, Klęski u'ojemne. [Warszawa]

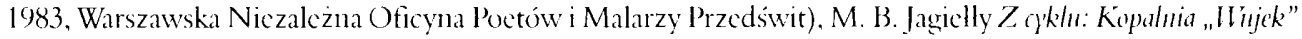
(..Obraz” 1985, ur 12. s 10-13).

22 Zob. mp. anonimowy wicrsz Pannięci Bogdama 117osika w antologii: Zapommisz...?. cz. 1.: Polska pieta, Kraków 1984 (Biblioteka ... Obserwatora Wojenncgo").

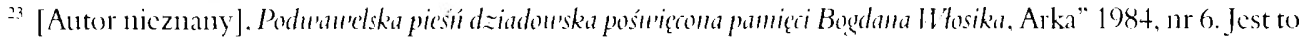
pewnic jednak raczej utwór stylizowany niz autentyczna ballada ludowa.

it Zob. J. Polkowski. Ogieni. Z notatek 1982-1983, [Kraków] [1983] (Pólka Poctów).

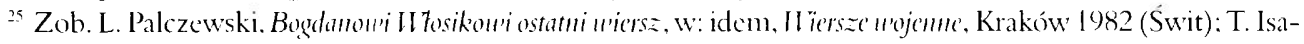
kowicz-Zaleski, Bogdan. w: idem, Irspommicnia. Kraków 1985 (Rota).

26 Matki. ..Arka“ 1985, nr 10.

${ }^{7}$ Np. Ból M. Michalskicj-Szybowskicj (M. Korczak [M. Michalska-Szybowska] Krople, [Warszawa] 1983 [b.w.]) czy jedna z calostek, z których sklada siç poemat T. Karpowicza Rozu'iez)'u'anic pizestrzconi (T. Karpo-

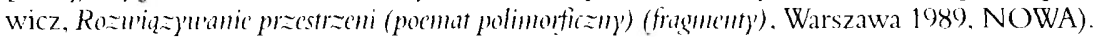




\section{Coście Matce mówili wydając skatowane ciało Jej własnego Chrystusa XX wiekı? ${ }^{2-8}$}

W ten sposób Przemyk zaliczony zostaje do grona świętych męczenników, jego śmierć zaś — zrównana z ofiarą Chrystusa. To jednak propozycja w swym radykalizmie dość odosobniona. Na ogól w wierszach poświęconych temu warszawskiemu licealiście najistotniejsza jest wspólnota cierpienia - ból matki rozlewa się na wszystkich, wszyscy zostają tą stratą w jakiś sposób dotknięci, wszyscy czują się z zabitym chłopcem spokrewnieni. Dlatego Jarosław Broda może napisać: ,zabijają nasze dzieci”"2, a Woroszylski przedstawić kondukt pogrzebowy w następujący sposób:

\section{Idzie miasto Grzesia \\ jego ulice i obloki \\ matki i bracia \\ wszystkie wróble i dzwony ${ }^{31}$.}

W pogrzebie uczestniczy więc cala cierpiąca wspólnota, cala wielka rodzina — „naród Grzesia”31. Śnierć chłopca, jednego z „nas”, wzmaga też poczucie zagrożenia całej wspólnoty, przekonanej, że to doświadczenie może się powtórzyć Dlatego niemal identycznie, stwierdzeniem o czekaniu na swoją kolej, pointują poświęcone Przemykowi wiersze Jarosław Broda i Piotr Szafarz ${ }^{32}$. Podobnie w utworze podpisanym pseudonimem Jota i pełniącym rolę wstępu do tomu poezji Grzegorza Przemyka śmierć jest doświadczeniem wspólnym, dotyczy ,nas wszystkich":

$$
\begin{aligned}
& \text { jakby nam wszystkim naraz } \\
& \text { strzaskano wątroby, odcbrano powietrze }
\end{aligned}
$$

Wielu twórców odwoluje się do tego tragicznego wydarzenia w sposób aluzyjny. Podstawą nawiązania może być data, a także często pojawiające się slowa-znaki: „maj” i „matura”34.

2* [H. T. Grodzicka-Królak] T. Boguszewska, I przeszedt Bóg dolimą krz)'w'dy. Zbiorek uriersz)' pisanyed grudzien 81-listopad 84. [b.m1.| |1985] [b.w.]. s. 56.

2" Po śmierci Graesia Przemyka, w: J. Broda. Pozostanmy im uphór broni. Wroclaw 1986 (Aspekt, Bibliotcka ..Obecności").

"W. Woroszylski, Kondukt. „Nowy Zapis" 1983. nr 4/5, s. 3.

${ }^{3}$ Bardzo podobny opis pogrzchu l’rzemyka jako wydarzenia absorbującego calą wspólnotę zawarl józef Ratajczak w wierszu Finisz z tomu Spisanc z muróu. Warszawa 1991.

32 [1. Szafarz] K. Hasta, Pamę̧ci G. Pracm)k'a. w antologii: Temu miastu. Gdańsk 1985 (Wydawnictwo Kontaktów).

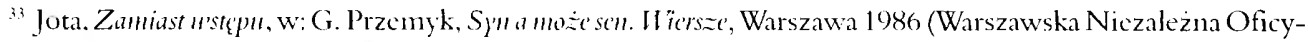
na Poctów i Malarzy Przedświt). s. 3.

${ }_{34}$ Wyczulenia cenzury na kontekst stowa ..matura" dowodza restrykcje. które przypadkowo spotkaly w tym czasie utwór zespolu rockowego Lady Pank. Muncj niz zéro z wersenn: „zaliczona matura na piçć” (zob. A. Sowa, Zakazane proscnki. .Życie" 1996. nr 30, s. 14). 
Zresztą daty takich poruszających opiniç publiczną zdarzeń w ogóle odgrywają w poezji dość istotną rolę - wielu poetów obiera je potem za tytuly swoich tekstów, zakładając, że ich wymowa będzie dla odbiorcy zrozumiała (tworzy się w ten sposób caly martyrologiczny kalendarz) - na przyklad kilku autorów pisze wiersze, które mają w tytule datę 16 grudnia — dzień pacyfikacji kopalni „Wujek”.

Przypadek Grzegorza Przemyka jest jednak dość szczególny. Bowiem, oprócz omówionych tutaj utworów, postać zabitego chlopca pojawia się także w poezji samej Barbary Sadowskiej. Są to jednak wiersze zupełnie odmienne, wyróżniające się niezwykle ściszoną tonacją. Można w nich również odnaleźć ślady polemiki ze stereotypową frazeologią obecną w wielı tekstach okolicznościowych. Sadowska zdecydowanic odrzuca sposób, w jaki przyjęto opisywać i interpretować śmierć jej syna:
nie mówcie przy mnie
o maju
o dzieciach
o maturach
o bohaterstwic
o przyszłości
nie mówcie przy muie
o umarłym ziarnie
które wyda owoc ${ }^{35}-$

— przeciwstawia mu natomiast bardzo indywiduahnie traktowaną plaszczyznę odniesień religijnych. Poetka dostrzega i zapisuje to, jak jej prywatna tragedia staje się przedmiotem taniej sensacji, zmienia w latwe do wykorzystania „czytelne historyjki obrazkowe”:
i popatrz dawni i nowi znajomi
żując coś opowiadają wrażenia
z pogrzebu
jesteśmy ich gumą do żucia
którą obawiają się wypluć

Zaś mieszkanie, które w wierszu podpisanym psendonimem Jota było miejscem gromadzenia się pogrążonej w żalobie wspólnoty, nieomal bastionem „wiszącym nad Warszawą” pełnym kwiatów, ludzi i muzyki, z jej perspektywy jawi się jako obce i nieprzyjazne:

przycupniçta na krześle

mieszkam teraz

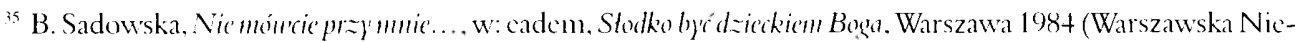
zależna Oficyna Poctów i Malarzy Przedświt), s. 8. Z publikowanych pośnicrci poetki wspomuicní wynika. że równicż w życin prywatnym była zdecydowaną przcciwniczką martyrologicznych celcbracji (zob. M. Safari, Nic món'ie przy muic o maju, o dzieciad, o muturach, „Tu, Teraz. Okupacyjne pismo nanczycicli” 1989, $11 \mathrm{r} 77$. s. 15).
} 


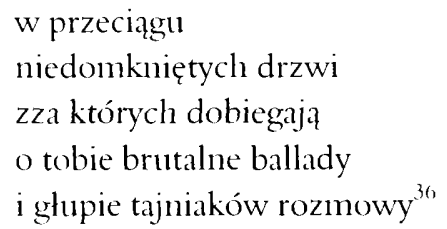

Te same drzwi, o których pisał w swoin tekście Jota, zamiast wyznaczać granicę wspólnoty, otwierają tutaj przestrzerí samotności.

W okresie stanu wojennego poeci bardzo chętnie sięgali po temat martyrologiczny. Śmierć w naturalny sposób wpisywala się bowiemn w ogólnąa atmosferę pesymizınu. W związku z tym wiele tekstów powraca także do wydarzeń z przeszłości, zwłaszcza tych, które dają się wlączyć w ciąg tradycji martyrologicznej. Przypominany więc zostaje i Grudzień ‘70, i poznański Czcrwiec. W 1983 rokı ukazuje się poświęcony prawie w calości temu ostatniemu tom Romana Chojnackiego Apel poleghydl i inne uicrsze (Poznań, Głosy, 1983). Tytułowy Apel polegtych to bardzo rozbudowany zapis relacji ofiar obu stron konfliktu z 1956 roku. Dawni i współcześni zabici zostają więc zespoleni pod wspólnym sztandarem cierpienia za ojczyznę. Takie właśnie przesłanie zjednoczenia w imię walki o wolność odczytać można na przykład z cyklu próz poetyckich Wlodzimierza Paźniewskiego. W jednej z nich, zatytułowanej Biegnacy przez historie ${ }^{37}$, poeta dokonuje nawet charakterystycznego utożsamienia: Romek Strzałkowski, Janek Wiśniewski, Bogdan Włosik stają się wlaściwie jedną postacią. W ten sposób powstaje swoiste ,martyrologiczne zaplecze”, z którego w miarę potrzeby wydobywa się odpowiednie przykłady.

Czasem, choć bardzo rzadko, do grona tego zaliczany bywa także Stanisław Pyjas. Jest to jednak postać, która najmniej poddaje się tendencjom unifikacyjnym. W odróżnieniu od wszystkich dotychczas wymienionych, Pyjas nigdy nie stał się bohaterem „ludowym”, przywolywanym w amatorskiej poezji wychıwalającej heroizm ofiary złożonej „za sprawę”. Wynikało to w dużej mierze z tego, że jego tajemnicza i po dzień dzisiejszy niewyjaśniona śmierć miala miejsce w zupehnie odmiennej sytuacji społeczno-politycznej. Pyjas zginął w maju 1977 roku, a więc jeszcze przed jednoczącym i aktywizującym szersze kręgi spoleczeństwa doświadczeniem Sierpnia. Jeśli więc to wydarzenie doczekało się poetyckich reperkusji, to jedynie w postaci utworów powstających w elitarnych kręgach opozycyjnych, często bliskich Komitetowi Obrony Robotników, z którym sam zabity byl związany. Wiersze te to prawie bez wyjątku utwory aluzyjne, nawiązujące do okoliczności opisywanego zdarzenia. Ciało Stanislawa Pyjasa znaleziono 7 maja 1977 w bramie kamienicy przy 11 . Szewskiej w Krakowie. I wlaśnie to miejsce i data stanowią podstawę licznych aluzji - tak jest na przykład u Jarosława Brody i u Jerzego Ficowskiego ${ }^{38}$. Czasem są to alızje bardzo ironiczne, przefiltrowane

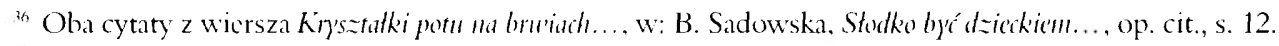

37 [W. Paźnicwski| A. Zawicja. Prosź̨ siç rozcjóć..., op. cit.

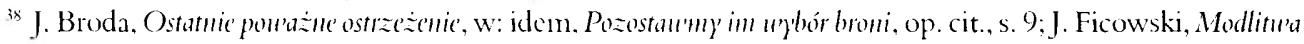
$\approx$ a Stamistana Pyjasa. w: idem, Gryps. Warszawa 1979 (NOWA).
} 
przez propagandowe oświetlenie tej sprawy — jak u Leszka Szarugii" ${ }^{39 y}$ Wlodzimierza Karpińskiego:

na szewskiej kilkı drabów

skopalo pijanego faceta ${ }^{+1}$.

Często tematem wierszy staje się znowu poczucie wspólnoty lączącej z zabitym, i trudno się oprzeć wrażeniu, że jednym z czynników je wytwarzających jest wlaśnie aluzyjny charakter omawianych tekstów, czytelnych jedynie dla wtajemniczonych, rozpoznających wzmianki o bramie, ulicy Szewskiej, nieznanych sprawcach itd. Choć oczywiście ten sposób mówienia bywa też receptą na uniknięcie nadmiernego patosu.

Podobna funkcja aluzji - kreowanie wspólnoty tych, którzy „wiedzą”, rozpoznają zakamuflowane odniesienia i polączeni są tym samym systemem wartości - zaistnieje także, choć na innym poziomie, w poezji stanu wojennego. Będzie to jednak wspólnota o nieco odmiennym charakterze - połączona wiedzą znacznie bardziej egalitarną niż ta, której w 1977 roku wymagała deszyfracja wspomnianych nawiązań. Wszystko to sprawiło, ze Stanisław Pyjas nie stał się nigdy bohaterem martyrologicznym na szerszą skalę, choć pojawiały się pewne próby nadania opisanym wypadkom wyższego sensu. Jarosław Broda w przywoływanym już utworze zwraca się do umierającego bohatera:

nie zapomnij w tej chwili

krzyknąć

za co giniesz

A więc nie jest to śmierć przypadkowa, ale również podporządkowana jakiemunś celowi. Podobną myśl wyraża Jan Korwin, który dedykuje wiersz Mur „Stanisławowi Pyjasowi poległemu w obronie wolności" ${ }^{+1}$. To więc także rodzaj ofiary, choć pozbawiony jeszcze sankcji religijnej, która będzie przysługiwać ginącym „za sprawę” w okresie stanu wojennego.

Poezja późniejsza - powstająca po 13 grudnia - także miała takich indywidualnych bohaterów, którzy nigdy nie stali się mieszkańcami patriotycznego panteonu. Należal do nich dziennikarz Jerzy Zieliński, który zginął śmiercią samobójczą na początku stanu wojemnego $^{+2}$, a także portretowana w sposób bardzo osobisty, najczęściej przez poetów z kręgı przyjaciół, Grażyna Kuroniowa ${ }^{+3}$. W tego typu utworach perspektywa osobista oddala jakąkolwiek interpretację ideologiczną.

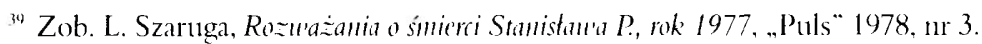

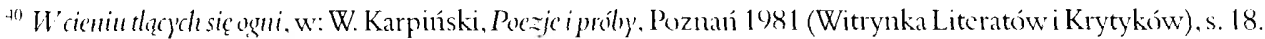

41 „Kultura” Paryz 1977, 1 r 6.

t2 Jemu poświęcone wiersze napisali Tomasz Jastrun (Chodnik, w: T. Jastrun Na ske żou'aniu . tzji i Europy', [Warszawa] 1983. Warszawska Niczalcżna Oficyna Poctów i Malarzy Przedświt) i Malgorzata Grześ (Jerzy' Ziclinski, „Puls“ Londyn 1982/1983, nr 17).

4.3 Pisali o nicj J. Zagórski (Gajka, w: J. Zagórski, Nie mru亡m) pouriek, Warszawa 1985. Warszawska Niczależna Oficyna Poetów i Malarzy Przedświt), S. Barańczak (Gmájnic, w: S. Barańczak. Atlamtrda i imme wiersze z lat 
Jednak wszystkie dotychczas omówione utwory ustępują znacznie pod względem liczebności wierszom poświęconym postaci księdza Jerzego Popiełuszki. Co charakterystyczne, po jego śmierci powstajz̨ nie tylko pojedyncze teksty, ale i cale tomy dedykowane pamięci zamordowanego kapłana. Są to między innymi książki Józefa Krupińskiego, Hanny Teresy Gro-

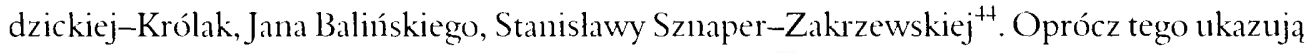
się też antologie poezji związanej z tym wydarzeniem ${ }^{\text {th }}$. Antologie te zawierają również pokaźny wybór twórczości amatorskiej, co pokazuje, że wstrząs spowodowany morderstwem księdza Jerzego obudzil na chwilę nieco już przygaszony masowy ruch wierszopisarski, który wspóltworzyl popularną literaturę stanu wojennego. Nie trzeba dodawać, że w tej sytuacji powstaje cała masa tekstów o bardzo nikłej wartości artystycznej.

W utworach poświęconych Popieluszce dominują dwa wątki. Po pierwsze ksiądz Jerzy portretowany jest jako męczennik za wiarę, a więc ktoś, kogo udzialem staje się świętość (trop częsty zwlaszcza w utworach amatorskich). Bywa zatem opisywany „w aureoli światta” (na przyklad w Nad ciemnościami Wisty' Krupińskiego). Ów rys świętości, naśladowanie Jezusa, polega też na przebaczeniu oprawcom. Ten wątek również akcentowany jest najczęściej w poezji amatorskiej, choć pojawia się także u Kazimierza Józefa Węgrzyna i Anny Kamieńskiej ${ }^{\dagger 0}$. Drugi wątek, obecny zwłaszcza w wierszach z dominującą tonacją patriotyczną, to nakładanie na morderstwo kapelana .Solidarności” interpretacji, którą można by określić mianem ideologicznej. Jego śmierć jest tu ukazywana jako ofiara zlożona za Polskę, za jej wolność (nieco podobnie jak w przypadku górników z kopalni „Wujek” w popularnej poezji z początków stanu wojennego). Takie stwierdzenia pojawiają się masowo w twórczości amatorskiej, a także często w tekstach Bolesława Piasta, Hanny Grodzickiej-Królak czy Grażyny Adamskiej ${ }^{+7}$. Oczywiście ten typ ujęć automatycznie wprowadza niezwykle podniosłą tonację. Utwory posługujące się nim pehne są patetycznych stwierdzeń podkreślających wagę złożonej ofiary, w rodzaju:

1981-1985. Wroclaw 1987. Aspekt) i W. Woroszylski (Doktór i Big. w: W. Woroszylski. Lustro. Dziennik intcrnomamia. Tituj. Londyn 1984).

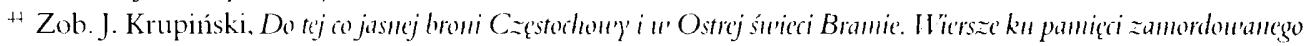
ksiegdza] Jerzego Popietus=ki. [b.m.] [ 1984] [b.w.]: T. Boguszewska [H. T. Grodzicka-Królak], Gdy ptakiskenlity sie w' gnicazdach. [b. m.] [1985?] [ [b.w.|: ]. Baliński, Dla Ciebie Polsko. Whotdzie Ks. Jerzemu Popietuszec, wst. ks. T. Bogucki, Warszawa 1987 [b. w.]; S. Sznaper-Zakrzewska. Tipptyk o ksig̨dzu Jerzym (poemat), opr. red. W. Huzik. Warszawa 1989 (Exlibris). Powstala też (niczhyt udana) powieść osnuta wokól tych wydarzeń (zob.

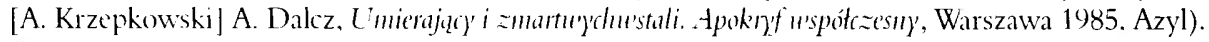

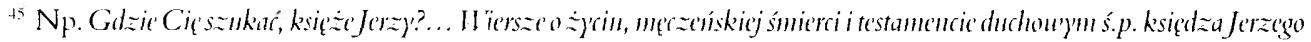
Popietuszki. [Warszawa] 1985. Kret (tom zalwiera wylącznc utwory amatorskic, w liczbie ponad siedendziesięcill. a jak zaznaczają autorzy we wstępic. jest to zaledwie część dostępnego im materialu) i Ksiz̨dz Jerzy' ' poezji i pieśni, opr. ks. A. Lewek, Warszawa 1986 [b.w.] (tu zgromadzone są wiersze nie tylko amatorów. ale też znanych poctów oraz picśni - których obecność świadczy o szybkin ksztaltowaniu siç kultu księdza Popicluszki).

to Zob. K. J. Węgrzyn. Noc u' kościcle śu'. Stanistan'a. w: idem, Czanne kuriaty' | Katowice| 1987 (Oficyna Śląska); A. Kamicńska Proj' grobie ks. Jerzego Popietuszki, w: Ksiądz Jerz)' 'u' poezji i pieśni, op. cit.

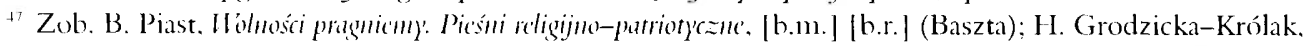

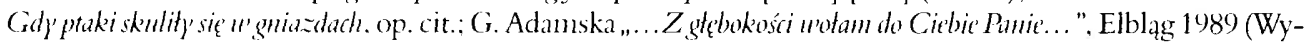
dawnictwo ., Solidarność"). 
z krwawej ofiary Świętego Kapłania

zrodzi się Polska

(I I. Grodzicka-Królak Byteś wolnościq...);

na polskim krzyżu umarł za nas

(G. Adamska Trudno sercu ludzkicmun...).

Wiersze mówiące o sprawie księdza Popiełuszki często także skupiają uwagę na jego rodzicach (na przykład Jan Baliński pisze utwór Rodzicom Ks. Jerzego). Wyeksponowana tu zostaje zwłaszcza postać matki (jak w utworach podpisanych Robotnica w tomic Ksiądz Jerzy' '" poezji i pieśni), jej ból nasuwa skojarzenia z cierpieniem Matki Boskiej — tak jest zarówno w ano-

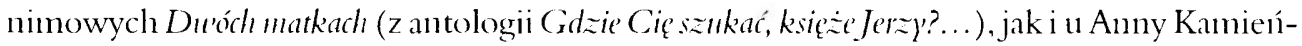
skiej (wiersz Matce ks. Jerzego drukowany w antologii Ksiądz Jerzy' u' poezji i pieśni).

Odniesienia do Matki Boskicj sạ jednym z elementów uświęcania postaci zamordowanego kaplana. Ta sakralizacja dokonuje się zresztą na wiele różnych sposobów. Część wierszy opisuje okoliczności śmierci księdza przy użyciu sformułowań zazwyczaj używanych w odniesieniu do męki Jezusa. Tak na przykład w tekście zatytułowanym 30. X. 1984 postępuje Bogusław Kierc ${ }^{48}$. Szczególnie często rzeczowniki takie jak „ciało” i „grób” zostają zapisane wielką literą. Zabieg ten stosuje zwłaszcza I lanna Grodzicka-Królak.

Przyszlo tysiące nas,

aby Cialo złożyć do grobu ${ }^{+4}$

— tak rozpoczyna się w jednyın z jej wierszy opis pogrzebu. Z kolei Tadusz Szyma przywołuje skojarzenie z namaszczenièm ciala Jezusa — wodę z zalewu, w którym znaleziono cialo księdza, porównuje do „Świętego oleju”" ".

Najbardziej konsekwentnie, ale też w sposób najbardziej indywidıalny, przeprowadza takie sakralizujące porównanie Stanisław Barańczak. Jednak pozbawione jest ono jakicjkolwiek ideologicznej interpretacji i polega wyłącznie na zestawieniu dwóch obrazów cierpienia zamykających każdą z części utworu noszącego tytuł Msza za Polskęu' St. Paul's Churdh, grudzień 1984:

dtonie przebite ću'ickami; za plecami zuriqzane dtonic (...)

gtou'a u' ciemiach; patkami zmasakrou'ana gtou'a (...)

"rotanie znad belki krzyza; uderzenia " bagażnik fiata

Brak tu też bezpośrednich odniesień, najbardziej konkretne to chyba „bagażnik frata” i wskazany w tytule koniec 1984 roku. Barańczakowi udaje się również uniknąć nadmiernego

t* Zob. B. Kierc, Modlitu'a praecine rozpaz), Wroclaw 1985 (Fcniks. Biblioteka Solidarności Walcząccj). Tu znów tytulem wiersza staje siç data nie poparta żadnym wyjaśnienicm, a więc zalożono, że jej sens bçdzie dla odbiorcy zrozumialy - w tym wypadku chodzi o dzień odmalezicnia zwłok ksiçdza.

t9 Przyszto t]siące mas..., w: [I I. T. Grodzicka-Królak] T. Boguszewska, I przeszedt Bóg.... op. cit. s. 93.

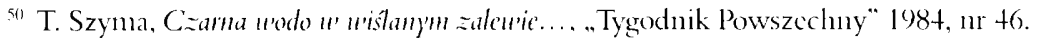

51 S. Barańczak, Atlantyda i imme wiersze..., op. cit., s. 18. 
patosu - zacytowane fragmenty zostały wydzielone z utworu (także graficznie) i w wyraźny sposób skontrastowane z resztą tekstu, która mówi o tym, że zarówno zachowanie zebranej w St. Paul's Church wspólnoty, jak i rozważania podmiotu wiersza daleko odbiegają od heroizmu Co ciekawe, te rozważania dotyczą także śpiewanej podczas mszy pieśni, a zwłaszcza jej artystycznych ulomności; wynika też z kontekstu, że może to być Ojczyzno ma..., a więc pieśń tradycyjnie lączona z postacią Popieluszki. Wlaściwie można uznać, że Msza za Polskę u' St. Paul's Church to, bardziej niż wiersz o wydarzeniach z października 1984 roku, utwór poświęcony rozważaniom o istocie cierpienia, więc właściwie mieszczący się w kręgu tematyki często przez Barańczaka podejmowanej.

Porównanie losu Jezusa i Popiehuszki pojawia się też w dość kontrowersyjnym, bardzo poruszającym wierszu I Ienryka Grynberga Nie ukrzyżoualiby:

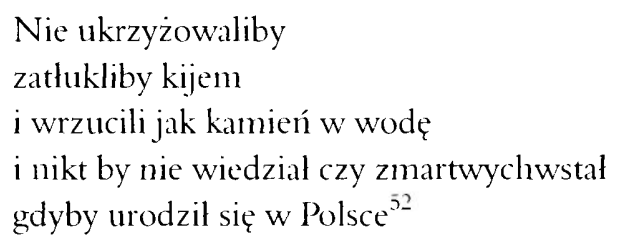

Wynika z niego, że doświadczenie, które spotkało księdza Jerzego, jest jeszcze bardziej okrutne od śmierci krzyżowej.

Znaczna część utworów - zwłaszcza tych o większej wartości artystycznej - nawiązuje do postaci księdza Jerzego w sposób aluzyjny (na przykład u Grynberga bezpośrednie odniesienie stanowi tylko dedykacja), jedynie twórczość amatorska nie skąpi tu jawnych odwołań. Takim znakiem odniesienia może być przywołanie żoliborskiego kościoła pod wezwaniem świętego Stanisława Kostki - miejsca pochówku księdza, najczęściej jednak w tej roli występuje Wisla, często będąca motywem przewodnim wiersza ${ }^{53}$. Jedną ze wskazówek bywa również datowanie utworu na koniec października czy pierwsze dni listopada 1984 (na przyklad Zu'ycięstu'o Mieczyslawy Buczkówny ${ }^{5+}$ — napisane 3 listopada 1984 roku, czyli w dzień pogrzebu księdza Jerzego).

Tragiczna śmierć kapłana była wydarzeniem, które wstrząsnęło opinią publiczną. Stąd tak ogromna liczba poświęconych mu wierszy. Każdy poeta opozycyjny czul się zobowiązany do napisania przynajmniej jednego tekstı upamiętniającego kapelaıı „Solidarności” 55 . Nawet jeśli tekst ten przybieral — jak w wierszu Kornela Filipowicza - formę osobistego wyznania

52 „Kontakt” Paryż 1987, 1 r 1/2, s. 133.

53 Tak jest w przywoływanym już wicrszu Szymy. Podobnic u Brylla ( $\dot{Z} e^{\prime}$ mikt nic zna dnia ani godziny..., w: E. Bryll, List. Warszawa 1985. NOWA), Woroszylskicgo (O pótnocy kościelny' dzuon..., . Tygodnik Powszechny" 1984. nr 46). Kulmowej (IIista, .Obraz” 1984. 11r 11).

st "Tygodnik Powszechny" 1984, nr 50 ).

"Sawet Jacck Kaczmarski napisal piosenkę Epitafium dla księdza Jerzego (J. Kaczmarski, Przejście Polaków przez Morze Czenonc. Warszawa 1987. NOWA). 
o niemożności mówienia o tej sprawie. Rozważania Ośmierci księ̣dza koniczy dwuznaczne wezwanie:

$$
\text { Proszę niech o tym piszą inni } 5 \text {. }
$$

Jednak zjawisko tak ogromnego poetyckiego zainteresowania tym tematem wywolalo również falę krytyki (co pewnie wcześniej — na początku stanu wojennego - w tej formic byłoby nie do ponyślenia). Antoni Pawlak napisal bardzo gorzki wiersz o instrumentalnym i stereotypowym (konieczne elementy: szosa, kapitan Piotrowski, Wisla itd.) traktowaniu śmierci Popiełuszki. Pointa utworu Ka亡dy u'ieczór kończy się unerszem brzmi:

$$
\begin{aligned}
& \text { w ten sposób - panowic - przechodzi się } \\
& \text { do literatury }
\end{aligned}
$$

Oznacza to, że w poetyckim podejściu do tematu „męczennika politycznego” zaczyna się coś zmieniać. Literacki użytek zrobiony ze śmierci, z lıdzkiej tragedii, choćby wykorzystancj w patriotycznym celu, okazuje swoją niestosowność.

Przedstawiony przegląd wierszy upamiętniających ofiary politycznych zawirowań najnowszej historii daleki jest od kompletności. Nie chodziło tu bowiem o stworzenie katalogu okolicznościowych utworów „ku czci”, ale raczej o pokazanie, jak zmienial się obraz „politycznego męczennika" i sama interpretacja śmierci jako faktı politycznego w poezji na przestrzeni lat siedemdziesiątych i osiemdziesiątych. Obraz ten podlegal w tym czasie daleko idącym przeksztalceniom. Najpierw byla to obserwowana z duzego dystansu i obecna w poezji wlaściwie jedynie pośrednio tragedia Grudnia 1970; potem również przywolywane poprzez alızje, ale już dużo bardziej ukonkretnione, morderstwo Stanisława Pyjasa, które - w świetle przypomnianych utworów - jawi się jako fakt konsolidujący grupę opozycjonistów; jeszcze później przychodzi pora na wielką przemianę Sierpnia i otwarcie literatury na patriotyczny idiom romantyczny, w myśl którego śmierć staje się poświęceniem za sprawę. 1)opierojednak z perspektywy następnego etapu — stanu wojennego — ofiara ta zyskuje sankcję religijną. Takiej uświęcającej stylizacji poddaje się więc kolejne postaci związane z tragicznym bilansem wydarzeń pierwszej polowy lat osiemdziesiątych - górników z kopalni „Wujek”, Grzegorza Przemyka, księdza Jerzego Popiełuszkę. Ich wierszowane portrety czasem nabierają rysów indywidualnych, ale częściej chyba dominuje w nich czynnik unifikacji - zabici są prawie wyłącznie sprowadzeni do roli dowodów na nieludzkość reżimu. Niekiedy, zwłaszcza w późniejszym okresie, do glosu dochodza jednak pojedyncze sygnały sprzeciwu przeciw takiemu użytkowemu traktowaniu ludzkich losów.

Dzisiaj takich wierszy już nikt nie pisıje, i nawet sama idea ich pisania została dostatecznie skompromitowana. Pod gdańskimi krzyżami wciąż składa się okolicznościowe kwiaty. Ale monument ten jest bardziej pomnikiem idei niż ludzi. Nikt nie pamięta nazwisk umieszczo-

\footnotetext{
56 K. Filipowicz, Pouriedz to stouro, Poznani 1997, s. 76.

57 .Kultura“, Paryz 1985, nr 7/8, s. 56.
} 
nych na niewielkim krzyżu przy bocznej ścianie. Nikt, być może oprócz kilku dociekliwych historyków, nie wie, kim byli zastrzeleni tu robotnicy. Na pomniku umieszczono frazę „poeta pamięta", którą poeci stanu wojennego usprawiedliwiali się z kiepskich wierszy. Niewątpliwie przywołane utwory dowodzą, że poezja starala się pamiętać. Jest to jednak niestety często pamięć zmącona. 